\title{
The Synthesis of Diverse Adenosine 5'-phosphonate Analogues as Chain Terminators against Hepatitis C Virus (HCV)
}

\author{
Bo-Seung Kim, ${ }^{\dagger}$ Beom-Tae Kim, ${ }^{\dagger, t}$ and Ki-Jun Hwang* \\ Department of Chemistry, ${ }^{\dagger}$ Department of Bioactive Material Sciences, College of Natural Science, \\ ${ }^{¥}$ Research Center of Bioactive Materials, Chonbuk National University, Chonju 561-756, Korea \\ *E-mail:kijun@chonbuk.ac.kr \\ Received March 2, 2010, Accepted March 29, 2010
}

\begin{abstract}
Adenosine 5'-phosphonates have been reported as potential chain terminators against Hepatitis C virus (HCV); therefore, we developed convenient sequences for synthesis of modified adenosine 5'-phosphonates in which the hydroxyl group at 2' or 3'-position of the sugar moiety is substituted with the azido or amino group and the oxymethyl group at the 4'-position is modified by the ethylene or vinyl group. This synthetic sequence can provide six adenosine 5'-phosphonates via one protocol, and is considered to be very efficient and a convenient route of synthesis. An assay of adenosine 5'-phosphonate analogues $(\mathbf{1}, \mathbf{2}, \mathbf{3}, \mathbf{4}, \mathbf{5}$, and $\mathbf{6})$ against HCV infection is now in progress.
\end{abstract}

Key Words: Adenosine 5'-phosphonate, Chain terminators, Hepatitis C virus

\section{Introduction}

Hepatitis $\mathrm{C}$ virus (HCV) is the major causative agent responsible for non-A and non-B virally induced hepatitis, ${ }^{1}$ and it causes health problems worldwide. ${ }^{2}$ There are currently 170 million infected carriers of $\mathrm{HCV}$ worldwide, and that number is gradually increasing. Individuals who are infected with $\mathrm{HCV}$ but do receive treatment for the acute infection, generally develop chronic hepatitis. It has also been reported that as many as $20 \%$ of infected individuals develop liver cirrhosis, and that $1-5 \%$ subsequently develop hepatocellular carcinoma. ${ }^{3}$ The current therapy against chronic HCV infection is based on a combination of interferon- $\alpha$ and a nonspecific antiviral nucleoside analogue such as ribavirin. ${ }^{4}$ Unfortunately, this therapy has insufficient efficacy and considerable side effects; therefore, there is an urgent need to develop new and improved anti-HCV therapies in terms of both efficacy and safety.

Extensive studies have been conducted to develop new drugs for HCV infection. Recently, two inhibitors, NM $283^{5}$ and R$1626^{6}$ (Figure 1), have gained attention due to their potent antiviral effects in $\mathrm{HCV}$ infected patients. These agents work as nucleoside chain terminators against HCV NS5B RNA polymerase and are currently undergoing phase IIb clinical trials for the treatment of chronic HCV infection. Both agents are nucleosides that bear modified sugar moieties. In addition, R1626 has an azido group at the 4'-position of the sugar moiety. As evidenced by these agents, nucleoside chain terminators are one of the major classes of drugs targeting a viral polymerase, and several nucleoside chain terminators are clinically used as antiviral agents. ${ }^{7}$ Nucleoside phosphonates are nucleoside chain

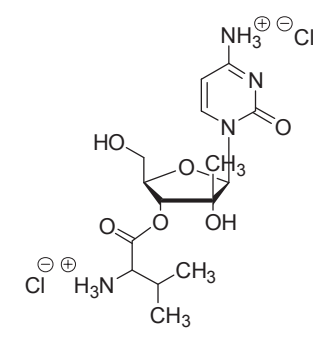

Valopicitabine dihydrochloride (NM283)

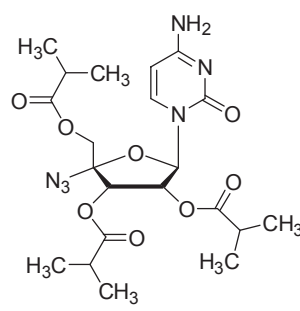

R-1626

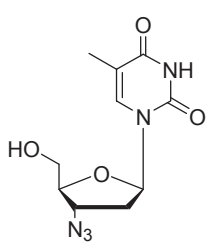

3'-Azido-3'-deoxythymidine (AZT)

Figure 1. Sructures of the inhibitors NM283, -1626, and AZT.

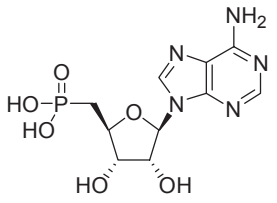

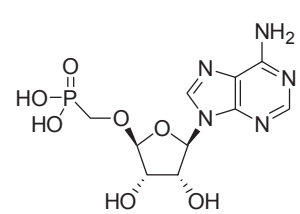

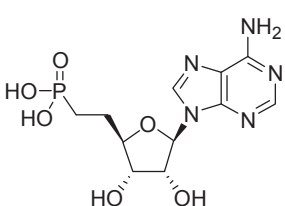

III

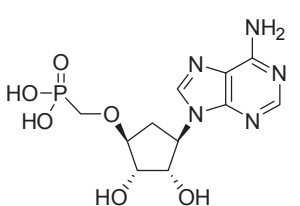

IV

Figure 2. Structures of nucleoside phosphonate analogues designed against HCV. 

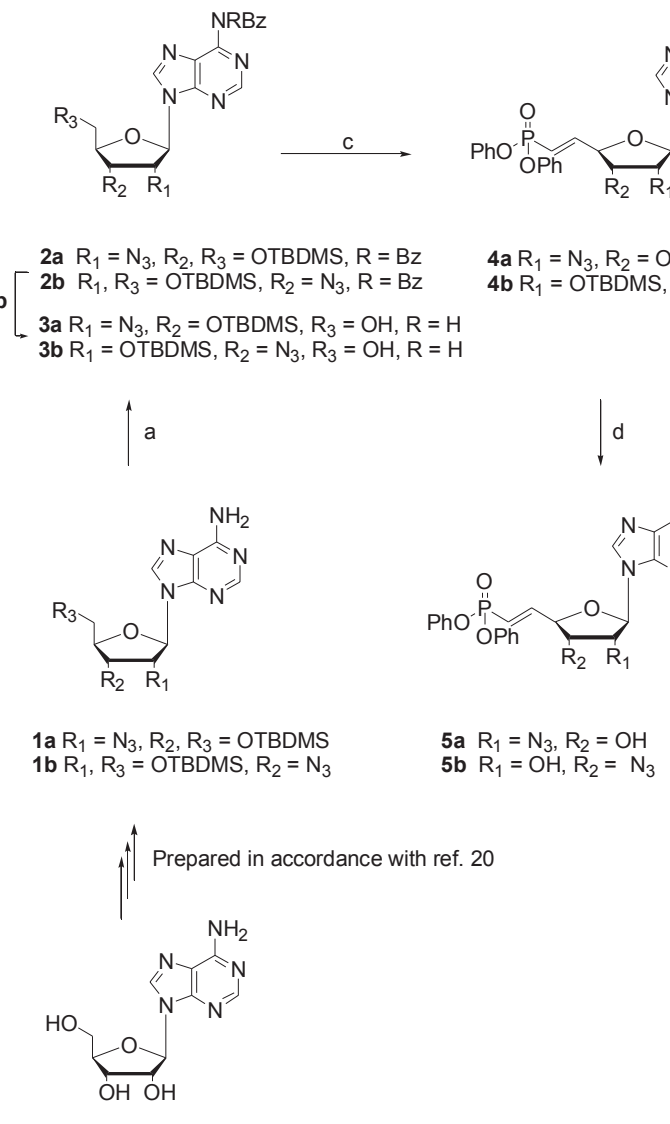

Adenosine

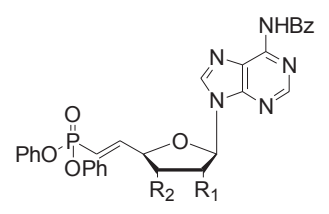

$$
\text { 4a } R_{1}=N_{3}, R_{2}=\text { OTBDMS }
$$

$4 b R_{1}=$ OTBDMS, $R_{2}=N_{3}$

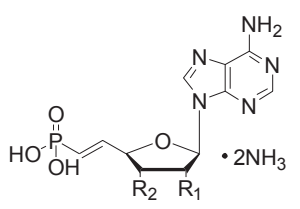

$1 \mathrm{R}_{1}=\mathrm{N}_{3}, \mathrm{R}_{2}=\mathrm{OH}$
$2 \mathrm{R}_{1}=\mathrm{OH}, \mathrm{R}_{2}=\mathrm{N}_{3}$
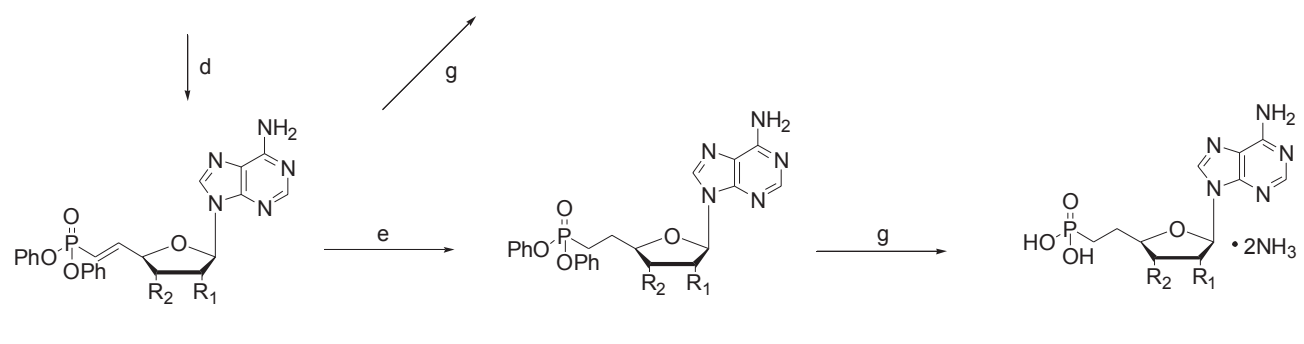

$6 a R_{1}=N_{3}, R_{2}=O H$ $3 \mathrm{R}_{1}=\mathrm{N}_{3}, \mathrm{R}_{2}=\mathrm{OH}$
$4 \mathrm{R}_{1}=\mathrm{OH}, \mathrm{R}_{2}=\mathrm{N}_{3}$

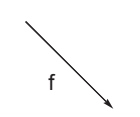

$6 b R_{1}=O H, R_{2}=N_{3}$

$$
\begin{aligned}
& 7 a R_{1}=N_{2}, R_{2}=O H \\
& 7 b R_{1}=O H \\
& R_{2}=N_{2}
\end{aligned}
$$

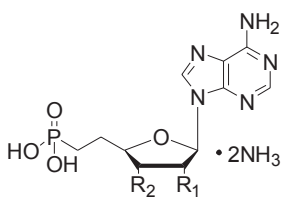

$5 \mathrm{R}_{1}=\mathrm{NH}_{2}, \mathrm{R}_{2}=\mathrm{OH}$ $6 \mathrm{R}_{1}=\mathrm{OH}, \mathrm{R}_{2}=\mathrm{NH}_{2}$

a) $\mathrm{BzCl}$, Pyridine, $0^{\circ} \mathrm{C}$; b) TFA $/ \mathrm{H}_{2} \mathrm{O}(9: 1, \mathrm{v} / \mathrm{v}), 0^{\circ} \mathrm{C}$; c) DCC, DMSO, TFA, Pyridine then, $(\mathrm{PhO})_{2} \mathrm{P}(=\mathrm{O}) \mathrm{CHPPh}_{3}$;

d) con. $\mathrm{HCl} / \mathrm{EtOH}\left(1: 99\right.$, w/w), $60^{\circ} \mathrm{C}$; e) $\left(\mathrm{KCO}_{2} \mathrm{~N}\right)_{2}, \mathrm{CH}_{3} \mathrm{CO}_{2} \mathrm{H}$, Pyridine; f) $\left.\mathrm{Pd} / \mathrm{C}, \mathrm{H}_{2}, \mathrm{MeOH} ; \mathrm{g}\right) \mathrm{NH}_{4} \mathrm{~F}, \mathrm{CH}_{3} \mathrm{CN}, \mathrm{H}_{2} \mathrm{O}, 60^{\circ} \mathrm{C}$

Scheme 1. Synthesis of diverse adenosine 5'-phosphonates (1-6).

terminators that function via a structurally isostere of nucleoside monophosphate. The presence of 4'-ethylphosphonate instead of phosphate, allows the first phosphorylation step required for nucleoside activation to be skipped, therefore jumping over this inefficient and often rate-limiting step in the conversion to 5'-triphosphate. Recently Koh et al. ${ }^{8}$ reported four different adenosine phosphonates that were designed to mimic adenosine monophosphate (Figure 2).

The compound III among others in Figure 2 attracted our attention for two reasons. First, the anti-HCV activity of this compound has already been proved and its biological activity likely occurs because the compound acts as a chain terminator due to the presence of a phosphonate group instead of phosphate group at the 4'-position of the sugar moiety. Second, since we previously developed the efficient methodology ${ }^{9}$ to introduce either an azido or amino group at the 2' or 3'-position of the sugar moiety, the development of nucleoside analogues containing the phosphonate group at the 4'-position and either an azido or amino group at the 2' or 3'-position of the sugar would be interesting. The importance of the azido and/or amino group in nucleoside drug has been demonstrated by the use of compound R-1626 and 3'-azido-3'-deoxythymidine (AZT) to treat
AIDS in figure 1. Here, we describe the efficient synthesis of $2^{\prime}$ (or 3')-deoxy-2'(or 3')-azido-adenosine 4'-vinylphosphonate $(\mathbf{1}, \mathbf{2}), 2^{\prime}($ or 3 ')-deoxy-2'(or 3')-azido-adenosine 4'-ethylphosphonate $(\mathbf{3}, \mathbf{4})$ and $2^{\prime}\left(\right.$ or $\left.3^{\prime}\right)$-deoxy-2'(or 3')-amino-adenosine 4'ethylphosphonate $(\mathbf{5}, \mathbf{6})$ starting from azido-adenosine analogues (1a, 1b) (Scheme 1).

\section{Results and Discussion}

2'(or 3')-Azido-2'(or 3')-deoxyadenosine derivatives (1a, 1b) were prepared in high yields as key intermediates according to the procedure described by Kim et al. ${ }^{9}$ To introduce the phosphonomethyl group to the 2'(or 3')-azido-2'(or 3')-deoxyadenosine derivatives $(\mathbf{1 a}, \mathbf{1 b})$, it is necessary to protect the $N^{6}$-amine group at adenine moiety and the hydroxyl groups at the sugar. So, first, 1a and $\mathbf{1 b}$ were protected with benzoyl chloride in pyridine at $N^{6}$-amine position to give dibenzoylated $\mathbf{2 a}$ and $\mathbf{2 b}$ with the isolated yields of $95 \%$ and $92 \%$, respectively. And then treatment of $\mathbf{2} \mathbf{a}$ and $\mathbf{2} \mathbf{b}$ with trifluoroacetic acid/water $(9: 1, \mathrm{v} / \mathrm{v})^{10}$ gave selectively $5^{\prime}$-desilylated- $N^{6}$-monobenzoyl adenosine $\mathbf{3} \mathbf{a}$ and $\mathbf{3 b}$ with the isolated yields of $93 \%$ and $85 \%$, respectively. Pfizner-Moffatt oxidation ${ }^{11}$ of $2^{\prime}$ or $3^{\prime}-\mathrm{TBDMS}-N^{6}$ - 
benzoyladenosines (3a, 3b) with 1,3-dicyclohexylcarbodiimide and pyridinium trifluoroacetate in DMSO produced a 5'-aldehydes, which were then directly reacted with diphenyl triphenylphosphoranylidenemethylphosphonate ${ }^{12}$ in situ to give their 5', 6'-vinylphosphonates $(\mathbf{4 a}, \mathbf{4 b})$ with the isolated yields of $45 \%$ and $65 \%$, respectively. The $400 \mathrm{MHz}$ nmr spectrum of 4 a showed the $\mathrm{C}_{6^{\prime}}$ proton as a quartet at $6.36 \mathrm{ppm}$ with $J_{6^{\prime}, 5^{\prime}}=17.2 \mathrm{~Hz}$, and $J_{\mathrm{H}, \mathrm{P}}=21.2 \mathrm{~Hz}$. The $\mathrm{C}_{5^{\prime}}$ proton was an octet at $7.04 \mathrm{ppm}$ with $J_{6^{\prime}, 5^{\prime}}=17.2 \mathrm{~Hz}, J_{\mathrm{H}, \mathrm{P}}=23.4 \mathrm{~Hz}$, and $J_{5^{\prime}, 4^{\prime}}=4.4 \mathrm{~Hz}$. And in the nmr spectrum of $\mathbf{4 b}$, the $\mathrm{C}_{5^{\prime}}$ proton was located within the aromatic envelope, while the $\mathrm{C}_{6}$ ' proton has triplet at $6.44 \mathrm{ppm}$ with $J_{6^{\prime}, 5^{\prime}}=17.4 \mathrm{~Hz}$. These date corresponded to those of previous report ${ }^{12}$ of a trans-isomer of vinyl phosphonate. And the yield of $\mathbf{4 a}$ was approximately $20 \%$ lower than that of $\mathbf{4 b}$, suggesting the steric effect caused by bulky 3'-TBDMS group of $\mathbf{4 a}$.

Next we moved on to hydrolyze TBDMS group at the 2 ' or $3 '$-position of the sugar ring, benzoyl group at $N^{6}$-adenine moiety. Generally the $N^{6}$-benzoyl group is cleaved by basic hydrolysis, with either methanolic ammonia ${ }^{8}$ or $1 \% \mathrm{NaOH}$ in methanol. ${ }^{13,14}$ However, we adopted acidic hydrolysis to cleave the benzoyl group and the TBDMS group in one step. Treatment of compound $4 \mathbf{a}$ and $\mathbf{4 b}$ with $1 \% \mathrm{HCl}$ in ethanol at $60{ }^{\circ} \mathrm{C}$ provided the desired compound $\mathbf{5 a}$ and $\mathbf{5 b}$ with isolated yields of $96 \%$ and $81 \%$, respectively. Now the hydrolysis of diphenyl phosphonate esters $(\mathbf{5 a}, \mathbf{5 b})$ to phosphonic acids like compounds $\mathbf{1}$ and $\mathbf{2}$ needs some mention. Two methods for the removal of diphenyl esters of nucleoside diphenyl phosphonate have been reported to date. In the first method, alkaline hydrolysis of one phenyl group is followed by removal of a second phenyl by enzymatic hydrolysis using phosphodiesterase from Crotalus adamanteus venom. ${ }^{15}$ In the second method, transesterification of nucleoside diphenyl phosphonate with sodium benzoxide to dibenzyl phosphonate, followed by palladium-catalyzed hydrogenolysis of the benzyl esters is conducted. ${ }^{16}$ However, both of these methods are evidently inefficient and furthermore unacceptable for the production of our compounds.

Therefore, it was necessary to develop a new and efficient hydrolysis method of diphenyl phosphonate esters to free phosphonic acids under the mild condition. After several attempts, a mild and efficient procedure employing $\mathrm{NH}_{4} \mathrm{~F} / \mathrm{CH}_{3} \mathrm{CN} / \mathrm{H}_{2} \mathrm{O}$ at $60{ }^{\circ} \mathrm{C}$ was developed in our laboratory and the result was published elswhere. ${ }^{17}$ This reaction condition was successfully applied to the diphenyl phosphonate nucleosides $(\mathbf{5 a}, \mathbf{5 b}, \mathbf{6 a}, \mathbf{6 b}, \mathbf{7 a}$, and $7 \mathbf{b})$ in the present study to provide the desired phosphonic acid nucleosides $(\mathbf{1}, \mathbf{2}, \mathbf{3}, \mathbf{4}, \mathbf{5}$, and $\mathbf{6})$. In a meantime, the vinyl group in compound $\mathbf{5 a}$ and $\mathbf{5 b}$ was selectively reduced to give $\mathbf{6 a}$ and $\mathbf{6 b}$ without affecting azido group by adopting diimide reduction ${ }^{18}$ with the isolated yields of $88 \%$ and $94 \%$, respectively, without affecting the azido group by adopting diimide reduction. ${ }^{18}$ Moreover, Pd-catalyzed hydrolysis of $\mathbf{5} \mathbf{a}$ and $\mathbf{5 b}$ reduced not only the double bond of the vinyl group but also azido group to amine to provide $7 \mathbf{a}$ and $\mathbf{7 b}$ with the isolated yields of $88 \%$ and $99 \%$, respectively. The aforementioned hydrolysis procedure for the diphenyl phosphonate esters $(\mathbf{5 a}, \mathbf{5 b}, \mathbf{6} \mathbf{a}, \mathbf{6} \mathbf{b}, \mathbf{7 a}$, and $\mathbf{7 b})$ was employed to provide the final product $\mathbf{1}, \mathbf{2}, \mathbf{3}, \mathbf{4}, \mathbf{5}$ and $\mathbf{6}$. The purification of the final products involves ion-exchange chromatography on DEAE-Sephadex $\left(\mathrm{HCO}_{3}{ }^{-}\right)$to provide the ammonium salt of adenosine 5'-phosphonic acids $(\mathbf{1}, \mathbf{2}, \mathbf{3}, \mathbf{4}, \mathbf{5}$, and 6) with the yields ranging from 70 - $82 \%$.

In summary, we designed and synthesized 4'-alkyl substituted nucleosides containing azido or amino group at the 2' or 3'position as nucleoside chain terminators. In these sequential synthetic procedures, we developed several methodologies that could be utilized conveniently in protection/deprotection in sugar chemistry. That is, the removal of both the TBDMS group and the benzoyl group under acidic condition (con. $\mathrm{HCl} / \mathrm{EtOH}$ $\left.(1: 99, \mathrm{w} / \mathrm{w}), 60{ }^{\circ} \mathrm{C}\right)$ was noteworthy. Also the reaction condition developed here $\left(\mathrm{NH}_{4} \mathrm{~F}, \mathrm{CH}_{3} \mathrm{CN}, \mathrm{H}_{2} \mathrm{O}, 60^{\circ} \mathrm{C}\right)$ to hydrolyze diphenyl esters of diphenyl phosphonate analogues to the corresponding phosphonic acid analogues is believed to be excellent when compared to the results reported in previous studies, in terms of yields, reaction time, and reaction handling. Evaluations of the effects of adenosine 5 '-phosphonate analogues $(\mathbf{1}, \mathbf{2}, \mathbf{3}$, $\mathbf{4}, \mathbf{5}$, and $\mathbf{6}$ ) against $\mathrm{HCV}$ infection are now in progress.

\section{Experimental Section}

Solvents and reagents were obtained from commercial suppliers and used as received. TLC was conducted using a Merck TLC Silica gel $60 \mathrm{~F}_{254}$ plate. Flash chromatography was performed on a Merck silica gel 60 with a mesh of $0.040-0.063 \mathrm{~mm}$. Melting points were recorded on Electrothermal melting point apparatus and were uncorrected. NMR spectra were recorded at $400 \mathrm{MHz}$ and $600 \mathrm{MHz}$ for ${ }^{1} \mathrm{H} \mathrm{NMR}$ and $100 \mathrm{MHz}$ and 125 $\mathrm{MHz}$ for ${ }^{13} \mathrm{C}$ NMR on JEOL JNM- EX400 and JEOL JNMECA600 spectrometer, respectively. High resolution mass spectra (HRMS) were recorded on a Synapt HDMS (Waters, Milford, $\mathrm{MA})$.

$N$-(9-((2R,3S,4R,5R)-3-Azido-4-(tert-butyldimethylsilyloxy)-5-((tert-butyldimethyl silyloxy)methyl)-tetrahydrofuran2-yl)-9H-purin-6-yl)- $\mathrm{N}$-benzoylbenzamide (2a). To precooled $1 \mathbf{a}(612 \mathrm{mg}, 1.175 \mathrm{mmol})$ in pyridine $(10 \mathrm{~mL})$ at $0{ }^{\circ} \mathrm{C}$ was added $\mathrm{BzCl}(548 \mu \mathrm{L}, 4.70 \mathrm{mmol})$. The reaction mixture was then stirred for $4 \mathrm{~h}$ at $0{ }^{\circ} \mathrm{C}$, after which the reaction mixture was poured into cold sat. $\mathrm{NaHCO}_{3}$ solution $(100 \mathrm{~mL})$, and the resulting emulsion was extracted with EtOAc $(50 \mathrm{~mL} \times 2)$. The organic layer was washed with brine and filtered, dried over $\mathrm{MgSO}_{4}$, evaporated to give oily residue which was subjected to flash column chromatography to provide $\mathbf{2 a}$ as a white solid (817 $\mathrm{mg}$, 95\%,): mp $66-67{ }^{\circ} \mathrm{C} ;{ }^{1} \mathrm{H}-\mathrm{NMR}\left(400 \mathrm{MHz}, \mathrm{CDCl}_{3}\right) \delta 0.03$ (s, $3 \mathrm{H}), 0.06(\mathrm{~s}, 3 \mathrm{H}), 0.17(\mathrm{~s}, 3 \mathrm{H}), 0.20(\mathrm{~s}, 3 \mathrm{H}), 0.87(\mathrm{~s}, 9 \mathrm{H}), 0.97$ (s, 9H), 3.77 (dd, 1H, $J=11.6 \mathrm{~Hz}, 2.8 \mathrm{~Hz}), 3.94$ (dd, 1H, $J=$ $11.6 \mathrm{~Hz}, 3.6 \mathrm{~Hz}), 4.13(\mathrm{t}, 1 \mathrm{H}, J=3.6 \mathrm{~Hz}), 4.44(\mathrm{t}, 1 \mathrm{H}, J=$ $5.2 \mathrm{~Hz}), 4.71(\mathrm{t}, 1 \mathrm{H}, J=5.2 \mathrm{~Hz}), 6.18(\mathrm{~d}, 1 \mathrm{H}, J=5.2 \mathrm{~Hz})$, 7.33-7.86 (m, 10H), $8.28(\mathrm{~s}, 1 \mathrm{H}), 8.66(\mathrm{~s}, 1 \mathrm{H}) ;{ }^{13} \mathrm{C}-\mathrm{NMR}(100$ $\mathrm{MHz}) \delta-5.50,-5.37,-4.92,-4.70,18.09,18.41,25.73,25.94$, $62.08,65.04,72.58,86.05,86.11,128.69,128.86,129.45$, $130.56,132.94,134.09,143.09,143.37,152.31,152.71,172.23$.

N-(9-((2R,3S,4R,5S)-4-Azido-3-(tert-butyldimethylsilyloxy)-5-((tert-butyldimethyl silyloxy)-methyl)-tetrahydrofuran2-yl)-9H-purin-6-yl)- $\mathrm{N}$-benzoylbenzamide (2b). By the same procedure used to prepare $\mathbf{2} \mathbf{a}, \mathbf{1} \mathbf{b}$ was converted to $\mathbf{2} \mathbf{b}$ as a white solid (4.63 g, 92\%): mp 68 - $69{ }^{\circ} \mathrm{C} ;{ }^{1} \mathrm{H}-\mathrm{NMR}\left(400 \mathrm{MHz}, \mathrm{CDCl}_{3}\right.$ ) $\delta-0.14(\mathrm{~s}, 3 \mathrm{H}), 0.04(\mathrm{~s}, 3 \mathrm{H}), 0.13(\mathrm{~s}, 6 \mathrm{H}), 0.84(\mathrm{~s}, 9 \mathrm{H}), 0.94(\mathrm{~s}$, $9 \mathrm{H}), 3.85(\mathrm{~d}, 1 \mathrm{H}, J=9.6 \mathrm{~Hz}), 4.04(\mathrm{~d}, 1 \mathrm{H}, J=11.6 \mathrm{~Hz}), 4.08$ (t, $1 \mathrm{H}, J=4.8 \mathrm{~Hz}), 4.22(\mathrm{~s}, 1 \mathrm{H}), 4.89(\mathrm{t}, 1 \mathrm{H}, J=4.8 \mathrm{~Hz}), 6.09$ 
$(\mathrm{d}, 1 \mathrm{H}, J=4.4 \mathrm{~Hz}), 7.33-7.87(\mathrm{~m}, 10 \mathrm{H}), 8.36(\mathrm{~s}, 1 \mathrm{H}), 8.66(\mathrm{~s}$, $1 \mathrm{H}) ;{ }^{13} \mathrm{C}-\mathrm{NMR}\left(100 \mathrm{MHz}, \mathrm{CDCl}_{3}\right) \delta-5.46,-5.29,-5.19,-5.01$, $17.88,18.45,25.53,26.00,61.23,62.59,76.88,82.45,88.82$, $128.13,128.64,128.87,129.44,130.57,132.85,134.14,134.51$, $143.17,151.87,152.21,152.73,172.17$.

$N-(9-((2 R, 3 S, 4 R, 5 R)-3-A z i d o-4-($ tert-butyldimethylsilyloxy)-5(hydroxymethyl) tetrahydro-furan-2-yl)-9H-purin-6-yl) benzamide (3a). 2 a (789 mg, $1.08 \mathrm{mmol})$ in $10 \mathrm{~mL}$ of TFA$\mathrm{H}_{2} \mathrm{O}(9: 1, \mathrm{v} / \mathrm{v})$ was stirred for $3 \mathrm{~h}$ at $0{ }^{\circ} \mathrm{C}$. The reaction mixture was then poured into cold $\mathrm{H}_{2} \mathrm{O}(50 \mathrm{~mL})$, extracted with EtOAc $(50 \mathrm{~mL} \times 2)$, washed with sat. $\mathrm{NaHCO}_{3}(50 \mathrm{~mL} \times 3)$ and brine $(50 \mathrm{~mL})$, dried over $\mathrm{MgSO}_{4}$, filtered and evaporated to give residue. The residue was purified by flash column chromatography to provide 3a as a white foam (513 mg, 93\%): $\mathrm{mp} 70$ $71{ }^{\circ} \mathrm{C} ;{ }^{1} \mathrm{H}-\mathrm{NMR}\left(400 \mathrm{MHz}, \mathrm{CDCl}_{3}\right) \delta 0.18(\mathrm{~s}, 3 \mathrm{H}), 0.21(\mathrm{~s}$, $3 \mathrm{H}), 0.98$ (s, 9H), 3.76 (d, 1H, $J=13.2 \mathrm{~Hz}), 3.99$ (dd, $1 \mathrm{H}, J=$ $13.2 \mathrm{~Hz}, 1.2 \mathrm{~Hz}), 4.25$ (s, 1H), 4.68 (d, 1H, J=4.8 Hz), 4.73 (dd, $1 \mathrm{H}, J=8.4 \mathrm{~Hz}, 4.8 \mathrm{~Hz}), 5.93$ (br s, 1H), 6.02 (d, 1H, $J=$ $8.4 \mathrm{~Hz}), 7.51-8.04(\mathrm{~m}, 5 \mathrm{H}), 8.11(\mathrm{~s}, 1 \mathrm{H}), 8.78(\mathrm{~s}, 1 \mathrm{H}), 9.20(\mathrm{br}$ $\mathrm{s}, 1 \mathrm{H}) ;{ }^{13} \mathrm{C}-\mathrm{NMR}\left(100 \mathrm{MHz}, \mathrm{CDCl}_{3}\right) \delta-4.89,-4.86,18.08$, 25.70, 62.68, 64.23, 74.16, 88.75, 89.76, 124.63, 127.89, 128.90, $132.96,133.37,142.73,150.50,150.52,152.24,164.48$.

$\mathrm{N}$-(9-((2R,3S,4R,5S)-4-Azido-3-(tert-butyldimethylsilyloxy)-5(hydroxymethyl)tetra hydro-furan-2-yl)-9H-purin-6-yl) benzamide (3b). By the same procedure used to prepare $\mathbf{3 a}, \mathbf{2 b}$ was converted to $\mathbf{3 b}$ as a white foam $(2.76 \mathrm{~g}, 85 \%): \mathrm{mp} 79-80^{\circ} \mathrm{C}$; ${ }^{1} \mathrm{H}-\mathrm{NMR}\left(400 \mathrm{MHz}, \mathrm{CDCl}_{3}\right) \delta-0.46(\mathrm{~s}, 3 \mathrm{H}),-0.08$ (s, 3H), 0.78 $(\mathrm{s}, 9 \mathrm{H}), 3.72(\mathrm{~d}, 1 \mathrm{H}, J=12 \mathrm{~Hz}), 3.97(\mathrm{~d}, 1 \mathrm{H}, J=12 \mathrm{~Hz}), 4.18$ $(\mathrm{s}, 1 \mathrm{H}), 4.28(\mathrm{~d}, 1 \mathrm{H}, J=5.6 \mathrm{~Hz}), 5.35(\mathrm{dd}, 1 \mathrm{H}, J=11.2 \mathrm{~Hz}, 5.2$ $\mathrm{Hz}), 5.83$ (d, 1H, $J=7.6 \mathrm{~Hz}), 6.04$ (br s, 1H), 7.86-7.33 (m, 5H), $8.03(\mathrm{~s}, 1 \mathrm{H}), 8.81(\mathrm{~s}, 1 \mathrm{H}), 9.25(\mathrm{~s}, 1 \mathrm{H}) ;{ }^{13} \mathrm{C}-\mathrm{NMR}(100 \mathrm{MHz}$, $\left.\mathrm{CDCl}_{3}\right) \delta-5.86,-5.10,17.74,25.47,63.32,63.71,74.80,85.43$, $90.91,124.28,127.87,128.35,128.91,132.98,133.41,142.96$, $150.34,150.57,152.36$.

Diphenyl (E)-2-((2R,3R,4S,5R)-4-azido-5-(6-benzamido9H-purin-9-yl)-3-(tert-Butyldime-thylsilyloxy)-tetrahydrofuran-2-yl)vinylphosphonate (4a). TFA $(303 \mu \mathrm{L}, 3.94 \mathrm{mmol})$ and pyridine $(106 \mu \mathrm{L}, 1.31 \mathrm{mmol})$ in anhydrous DMSO $(5 \mathrm{~mL})$ were stirred for $5 \mathrm{~min}$ at $\mathrm{rt}$. To this mixture, DCC (2.7 g, 13.12 $\mathrm{mmol})$ and $\mathbf{3 a}(670 \mathrm{mg}, 1.31 \mathrm{mmol})$ were added, and the reaction mixture was stirred for $24 \mathrm{~h}$ at $\mathrm{rt}$. And then diphenyl triphenylphosphoranylidenemethylphosphonate $(800 \mathrm{mg}, 1.7$ mmol) was finally added, and the mixture was stirred for further $10 \mathrm{~h}$ at $\mathrm{rt}$. To this mixture, oxalic acid $(1.5 \mathrm{~g}, 11.8 \mathrm{mmol})$ in $\mathrm{MeOH}(3 \mathrm{~mL}$ ) was carefully added. The reaction mixture was subsequently filtered, and the insolubles were washed with $\mathrm{MeOH}(20 \mathrm{~mL})$. The combined filtrate was evaporated to give oily residue which was partitioned with EtOAc $(20 \mathrm{~mL})$ and water $(20 \mathrm{~mL})$. The organic layer was washed with sat. $\mathrm{NaHCO}_{3}$ $(20 \mathrm{~mL} \times 2)$, dried over $\mathrm{Na}_{2} \mathrm{SO}_{4}$, filtered, and evaporated to give an oily residue. The residue was subjected to flash column chromatography to provide $4 \mathbf{a}$ as a white foam (433 mg, 45\%): $\mathrm{mp}$ $102{ }^{\circ} \mathrm{C} ;{ }^{1} \mathrm{H}-\mathrm{NMR}\left(600 \mathrm{MHz}, \mathrm{CDCl}_{3}\right) \delta 0.15$ (s, 3H), 0.18 (s, $3 \mathrm{H}), 0.96(\mathrm{~s}, 9 \mathrm{H}), 4.65(\mathrm{~s}, 1 \mathrm{H}), 4.66(\mathrm{~s}, 1 \mathrm{H}), 4.89(\mathrm{t}, 1 \mathrm{H}, J=4.8$ $\mathrm{Hz}), 6.36(\mathrm{dd}, 1 \mathrm{H}, J=21.2 \mathrm{~Hz}, 17.2 \mathrm{~Hz}), 7.04$ (ddd, 1H, $J=$ 23.4 Hz, 17.2 Hz, 4.4 Hz), 7.14-8.05 (m, 15H), 8.07 (s, 1H), $8.72(\mathrm{~s}, 1 \mathrm{H}), 9.09(\mathrm{~s}, 1 \mathrm{H}) ;{ }^{13} \mathrm{C}-\mathrm{NMR}\left(150 \mathrm{MHz}, \mathrm{CDCl}_{3}\right) \delta-4.89$, $-4.73,18.04,25.68,62.91,75.76,84.27$ (m), 87.41, $118.36(\mathrm{~m})$, $120.49,120.57,124.07,125.32(\mathrm{~m}), 127.87,128.89,129.79(\mathrm{~m})$, $132.91,142.66,149.11,150.00,150.12,151.39,152.79,164.54$.

Diphenyl $(E)-2-((2 R, 3 R, 4 S, 5 R)-3$-azido-5-(6-benzamido9H-purin-9-yl)-4-(tert-butyldimethylsilyloxy)-tetrahydrofuran-2-yl)vinylphosphonate (4b). By the same procedure used to prepare $\mathbf{4 a}, \mathbf{3 b}$ was converted to $\mathbf{4 b}$ as a pale yellow foam (1.26 g, 65\%): mp $72-73{ }^{\circ} \mathrm{C} ;{ }^{1} \mathrm{H}-\mathrm{NMR}\left(600 \mathrm{MHz}, \mathrm{CDCl}_{3}\right) \delta$ $-0.26,-0.01(\mathrm{~s}, 3 \mathrm{H}), 0.81(\mathrm{~s}, 9 \mathrm{H}), 4.03(\mathrm{t}, 1 \mathrm{H}, J=4.8 \mathrm{~Hz}), 4.69$ $(\mathrm{s}, 1 \mathrm{H}), 5.17(\mathrm{t}, 1 \mathrm{H}, J=4.8 \mathrm{~Hz}), 5.93(\mathrm{~d}, 1 \mathrm{H}, J=4.8 \mathrm{~Hz}), 6.44$ $(\mathrm{t}, 1 \mathrm{H}, J=17.4 \mathrm{~Hz}), 7.11-7.85(\mathrm{~m}, 16 \mathrm{H}), 8.03(\mathrm{~s}, 1 \mathrm{H}), 8.54(\mathrm{~s}$, $1 \mathrm{H}) ;{ }^{13} \mathrm{C}-\mathrm{NMR}\left(150 \mathrm{MHz}, \mathrm{CDCl}_{3}\right) \delta-5.26,-4.99,17.84,25.48$, $50.52,64.59,74.39,76.67,80.77,81.01,90.31,120.48,120.55$, 120.6, 125.38, 128.72, 129.44, 129.80, 129.84, 133.04, 133.97, $144.10,149.01,149.07,152.34,152.41,172.15$.

Diphenyl (E)-2-((2R,3R,4S,5R)-5-(6-amino-9H-purin-9-yl)4-azido-3-hydroxy-tetrahydrofuran-2-yl)vinylphosphonate (5a). 4 a (110 mg, $0.162 \mathrm{mmol}$ ) was dissolved in $5 \mathrm{~mL}$ of conc. HCl-Ethanol (1:99, w/w) solution, after which the mixture was stirred for $11 \mathrm{~h}$ at $60{ }^{\circ} \mathrm{C}$. The mixture was then neutralized with cold sat. $\mathrm{NaHCO}_{3}$ and extracted with EtOAc $(20 \mathrm{~mL} \times 3)$, dried over $\mathrm{Na}_{2} \mathrm{SO}_{4}$, and evaporated to give oily residue which was subjected to flash column chromatography to provide $\mathbf{5 a}$ as a white solid (74 mg, 96\%): mp $60-61{ }^{\circ} \mathrm{C} ;{ }^{1} \mathrm{H}-\mathrm{NMR}(400 \mathrm{MHz}$, $\left.\mathrm{CDCl}_{3}\right) \delta 8.25(\mathrm{~s}, 1 \mathrm{H}), 7.84(\mathrm{~s}, 1 \mathrm{H}), 7.30-7.06(\mathrm{~m}, 11 \mathrm{H}), 6.43$ (ddd, 1H, $J=22 \mathrm{~Hz}, 17.2 \mathrm{~Hz}, 2 \mathrm{~Hz}), 6.11$ (s, 2H), 5.94 (d, 1H, $J=4.8 \mathrm{~Hz}), 4.64(\mathrm{~s}, 1 \mathrm{H}), 4.60(\mathrm{t}, 1 \mathrm{H}, J=5.2 \mathrm{~Hz}) ;{ }^{13} \mathrm{C}-\mathrm{NMR}$ $\left(150 \mathrm{MHz}, \mathrm{CDCl}_{3}\right) \delta 63.91,74.33,83.15(\mathrm{~m}), 87.67,117.13(\mathrm{~m})$, $120.36,120.58(\mathrm{~m}), 125.44,129.83,139.93,149.39,149.93(\mathrm{~m})$, $150.29(\mathrm{~m}), 153.11,155.60$.

Diphenyl (E)-2-((2R,3S,4S,5R)-5-(6-amino-9H-purin-9-yl)3-azido-4-hydroxy-tetrahydro-furan-2-yl)vinylphosphonate (5b). By the same procedure used to prepare 5a, $\mathbf{4 b}$ was converted to $\mathbf{5 b}$ as a white solid (103 mg, 81\%): $\mathrm{mp} 68-69{ }^{\circ} \mathrm{C} ;{ }^{1} \mathrm{H}-\mathrm{NMR}$ $\left(400 \mathrm{MHz}, \mathrm{CDCl}_{3}\right) \delta 8.14(\mathrm{~s}, 1 \mathrm{H}), 7.86(\mathrm{~s}, 1 \mathrm{H}), 7.31-6.98(\mathrm{~m}$, $11 \mathrm{H}), 6.27$ (ddd, $1 \mathrm{H}, J=20.8 \mathrm{~Hz}, 16.8 \mathrm{~Hz}, 1.2 \mathrm{~Hz}), 6.16$ (s, 2H), $5.92(\mathrm{~d}, 1 \mathrm{H}, J=5.2 \mathrm{~Hz}), 4.93(\mathrm{t}, 1 \mathrm{H}, J=5.2 \mathrm{~Hz}), 4.70(\mathrm{~s}$, 1H), $4.23(\mathrm{t}, 1 \mathrm{H}, J=4.8 \mathrm{~Hz}) ;{ }^{13} \mathrm{C}-\mathrm{NMR}\left(100 \mathrm{MHz}, \mathrm{CDCl}_{3}\right) \delta$ 64.82, 74.39, 81.97 (m), 89.97, 118.38 (m), 119.93, 120.50 (m), $125.41,129.81$ (m), 139.59, 148.95, 149.62 (m), $149.93(\mathrm{~m})$, $152.53,155.43$.

Diphenyl 2-((2R,3R,4S,5R)-5-(6-amino-9H-purin-9-yl)-4azido-3-hydroxy-tetrahydrofuran-2-yl)ethylphosphonate (6a). To 5a (25 mg, $0.048 \mathrm{mmol})$ in pyridine ( $1 \mathrm{~mL})$, potassium azodicarboxylate $(47 \mathrm{mg}, 0.24 \mathrm{mmol})$ and acetic acid $(41 \mu \mathrm{L})$ were added sequentially. The reaction was then stirred for $25 \mathrm{~h}$ at rt. To this mixture, $5 \% \mathrm{HCl}$ solution $(10 \mathrm{~mL})$ was added and the mixture was extracted with EtOAc $(10 \mathrm{~mL} \times 3)$. The organic layer was washed with sat. $\mathrm{NaHCO}_{3}$ solution $(10 \mathrm{~mL} \times 2)$ and brine $(10 \mathrm{~mL})$, dried over $\mathrm{Na}_{2} \mathrm{SO}_{4}$, and concentrated in vacuo to give pale yellow solid, which was subjected to flash column chromatography to provide $\mathbf{6 a}$ as a white solid (22 $\mathrm{mg}, 88 \%$ ): mp 65 - $66{ }^{\circ} \mathrm{C} ;{ }^{1} \mathrm{H}-\mathrm{NMR}\left(400 \mathrm{MHz}, \mathrm{CDCl}_{3}\right) \delta 20.5-2.26(\mathrm{~m}, 4 \mathrm{H})$, $4.02(\mathrm{~m}, 1 \mathrm{H}), 4.55(\mathrm{t}, 1 \mathrm{H}, J=5.6 \mathrm{~Hz}), 4.75(\mathrm{dd}, 1 \mathrm{H}, J=5.6 \mathrm{~Hz}$, $4 \mathrm{~Hz}), 5.76(\mathrm{~d}, 1 \mathrm{H}, J=4 \mathrm{~Hz}), 6.20(\mathrm{~s}, 1 \mathrm{H}), 7.01-7.21(\mathrm{~m}, 10 \mathrm{H})$, $7.80(\mathrm{~s}, 1 \mathrm{H}), 8.19(\mathrm{~s}, 1 \mathrm{H}) ;{ }^{13} \mathrm{C}-\mathrm{NMR}\left(100 \mathrm{MHz}, \mathrm{CDCl}_{3}\right) \delta 21.02$ (m), $25.57(\mathrm{~m}), 65.05,74.15,83.12(\mathrm{~m}), 87.69,120.41(\mathrm{~m}), 125.34$ (m), 128.53, 129.81, 132.05, 139.80, 150.05, 153.00, 155.63 .

Diphenyl 2-((2R,3S,4S,5R)-5-(6-amino-9H-purin-9-yl)-3- 
azido-4-hydroxy-tetrahydrofuran-2-yl)ethylphosphonate (6b). By the same procedure used to prepare $\mathbf{6 a}, \mathbf{5 b}$ was converted to $\mathbf{6 b}$ as a white foam $(47 \mathrm{mg}, 94 \%)$ : $\mathrm{mp} 68-69{ }^{\circ} \mathrm{C} ;{ }^{1} \mathrm{H}-\mathrm{NMR}$ $\left(400 \mathrm{MHz}, \mathrm{CDCl}_{3}\right) \delta 2.12-2.33(\mathrm{~m}, 4 \mathrm{H}), 4.12(\mathrm{~s}, 2 \mathrm{H}), 5.21(\mathrm{~s}$, 1H), $5.93(\mathrm{~s}, 1 \mathrm{H}), 6.28$ (br s, 2H), 7.08-7.33 (m, 10H), 7.88 (s, 1H), $8.07(\mathrm{~s}, 1 \mathrm{H}) ;{ }^{13} \mathrm{C}-\mathrm{NMR}\left(100 \mathrm{MHz}, \mathrm{CDCl}_{3}\right) \delta 21.00,26.85$, 60.36, 64.86, $81.71(\mathrm{~m}), 89.48,120.31(\mathrm{~m}), 125.35,125.45$, $129.93,139.56,148.96,150.05,152.66,155.21$.

Diphenyl 2-((2R,3R,4S,5R)-4-amino-5-(6-amino-9H-purin9-yl)-3-hydroxy-tetrahydrofuran-2-yl)ethylphosphonate (7a). 5a (36 mg, $0.069 \mathrm{mmol}$ ) dissolved in $\mathrm{MeOH}(2 \mathrm{~mL})$ was hydrogenated under $\mathrm{H}_{2}$ atmosphere at $\mathrm{rt}$ for $10 \mathrm{~h}$ in the presence of $10 \% \mathrm{Pd} / \mathrm{C}(10 \mathrm{mg})$. The mixture was then filtered with the aid of celite and the filtrate was evaporated to give $7 \mathbf{a}$ as a white solid (30 mg, 88\%): mp $62-63{ }^{\circ} \mathrm{C} ;{ }^{1} \mathrm{H}-\mathrm{NMR}$ (400 MHz, MeOD) $\delta$ 2.23-2.33 (m, 4H), $4.15(\mathrm{~d}, 1 \mathrm{H}, J=2.8 \mathrm{~Hz}), 4.34$ $(\mathrm{dd}, 1 \mathrm{H}, J=6 \mathrm{~Hz}, 2.8 \mathrm{~Hz}), 5.23(\mathrm{t}, 1 \mathrm{H}, J=6 \mathrm{~Hz}), 6.00(\mathrm{~d}, 1 \mathrm{H}$, $J=7.2 \mathrm{~Hz}), 7.12-7.33$ (m, 10H), 8.13 (s, 1H), 8.22 (s, 1H); ${ }^{13} \mathrm{C}-\mathrm{NMR}$ (100 MHz, MeOD) $\delta$ 23.36, 27.42 (m), 56.17, 73.59, 86.77 (m), 88.42, 121.66 (m), 126.61, 130.98, 141.73, 150.86, $151.49,153.90,157.31,173.75$.

Diphenyl 2-((2R,3R,4S,5R)-3-amino-5-(6-amino-9H-purin9-yl)-4-hydroxy-tetrahydrofuran-2-yl)ethylphosphonate (7b). By the same procedure used to prepare $7 \mathbf{a}, \mathbf{5 b}$ was converted to $7 \mathbf{b}$ as a white solid (20 mg, 99\%): mp $62-64{ }^{\circ} \mathrm{C} ;{ }^{1} \mathrm{H}-\mathrm{NMR}$ (400 MHz, MeOD) $\delta 2.28-2.05$ (m, 4H), 3.50 (dd, 1H, $J=8.4$ $\mathrm{Hz}, 1.6 \mathrm{~Hz}), 3.85$ (m, 1H), 4.50 (dd, $1 \mathrm{H}, J=6 \mathrm{~Hz}, 2 \mathrm{~Hz}), 5.85$ $(\mathrm{d}, 1 \mathrm{H}, J=2 \mathrm{~Hz}), 7.22-7.01(\mathrm{~m}, 10 \mathrm{H}), 8.06(\mathrm{~s}, 1 \mathrm{H}), 8.08$ (s, $1 \mathrm{H}) ;{ }^{13} \mathrm{C}-\mathrm{NMR}(100 \mathrm{MHz}, \mathrm{MeOD}) \delta 14.45,27.06(\mathrm{~m}), 57.57$, 76.20, 84.89 (m), 92.10, 120.77, 121.68, 126.59, 130.94, 141.34, $150.25,151.56,153.89,157.35$.

Ammonium (E)-2-((2R,3R,4S,5R)-5-(6-amino-9H-purin-9yl)-4-azido-3-hydroxytetraydrofuran-2-yl)vinylphosphonate (1). 5a (40 mg, $0.077 \mathrm{mmol})$ and $\mathrm{NH}_{4} \mathrm{~F}(28 \mathrm{mg}, 0.77 \mathrm{mmol})$ were dissolved in $2 \mathrm{~mL}$ of co-solvent $\left(\mathrm{CH}_{3} \mathrm{CN}-\mathrm{H}_{2} \mathrm{O}=1: 1, \mathrm{v} / \mathrm{v}\right)$, and the reaction mixture was stirred for $3 \mathrm{~h}$ at $60^{\circ} \mathrm{C}$. The mixture was subjected to ion-exchange chromatography on EDAESphadex $\left(\mathrm{HCO}_{3}{ }^{-}\right)$; the column was washed with $100 \mathrm{~mL}$ of water, and eluted with $100 \mathrm{~mL}$ of $100 \mathrm{mM}$ ammonium bicarbonate. Then, the eluate was lyophilized to give 1 as a white solid (25 mg, 82\%): mp $76-77{ }^{\circ} \mathrm{C} ;{ }^{1} \mathrm{H}-\mathrm{NMR}\left(400 \mathrm{MHz}, \mathrm{D}_{2} \mathrm{O}\right) \delta 4.55$ $(\mathrm{t}, 1 \mathrm{H}, J=4.8 \mathrm{~Hz}), 4.58(\mathrm{~s}, 1 \mathrm{H}), 4.72(\mathrm{t}, 1 \mathrm{H}, J=5.6 \mathrm{~Hz}), 5.95$ $(\mathrm{d}, 1 \mathrm{H}, J=17.6 \mathrm{~Hz}), 6.01$ (d, $1 \mathrm{H}, J=5.6 \mathrm{~Hz}), 6.58$ (ddd, $1 \mathrm{H}$, $J=22 \mathrm{~Hz}, 17.6 \mathrm{~Hz}, 4.4 \mathrm{~Hz}), 8.11(\mathrm{~s}, 1 \mathrm{H}), 8.17(\mathrm{~s}, 1 \mathrm{H}) ;{ }^{13} \mathrm{C}-\mathrm{NMR}$ $\left(100 \mathrm{MHz}, \mathrm{D}_{2} \mathrm{O}\right) \delta 65.13,74.51,84.62(\mathrm{~m}), 86.87,122.29(\mathrm{~m})$, 130.34, 140.57, 144.40, 149.41, 153.64, 156.21; HRMS (ESI) calcd for $\mathrm{C}_{11} \mathrm{H}_{13} \mathrm{~N}_{8} \mathrm{O}_{5} \mathrm{P}$ 371.0981, found 371.0813.

Ammonium (E)-2-((2R,3R,4S,5R)-5-(6-amino-9H-purin-9yl)-4-azido-3-hydroxy-tetrahydrofuran-2-yl)vinylphosphonate (2). By the same procedure used to prepare $\mathbf{1 , 5} \mathbf{5}$ was converted to 2 as a white solid (17 mg, 80\%): mp $180{ }^{\circ} \mathrm{C} \mathrm{dec}$.; ${ }^{1} \mathrm{H}-\mathrm{NMR}$ $\left(400 \mathrm{MHz}, \mathrm{D}_{2} \mathrm{O}\right) \delta 4.24(\mathrm{t}, 1 \mathrm{H}, J=4.8 \mathrm{~Hz}), 4.50(\mathrm{~s}, 1 \mathrm{H}), 4.86$ $(\mathrm{t}, 1 \mathrm{H}, J=4.8 \mathrm{~Hz}), 5.88(\mathrm{~d}, 1 \mathrm{H}, J=4.8 \mathrm{~Hz}), 5.94(\mathrm{~d}, 1 \mathrm{H}, J=$ $17.2 \mathrm{~Hz}$ ), 6.52 (ddd, $1 \mathrm{H}, J=21.6 \mathrm{~Hz}, 17.2 \mathrm{~Hz}, 4.8 \mathrm{~Hz}$ ), 7.99 (s, $1 \mathrm{H}), 8.06(\mathrm{~s}, 1 \mathrm{H}) ;{ }^{13} \mathrm{C}-\mathrm{NMR}\left(100 \mathrm{MHz}, \mathrm{D}_{2} \mathrm{O}\right) \delta 66.63,75.47$, $83.87(\mathrm{~m}), 90.00,124.30(\mathrm{~m}), 131.74,142.32,145.85(\mathrm{~m})$, 150.94, 154.06, 156.97; HRMS (ESI) calcd for $\mathrm{C}_{11} \mathrm{H}_{13} \mathrm{~N}_{8} \mathrm{O}_{5} \mathrm{P}$ 371.0981 , found 371.0797
Ammonium 2-((2R,3R,4S,5R)-5-(6-amino-9H-purin-9-yl)4-azido-3-hydroxy-tetrahydrofuran-2-yl)ethylphosphonate (3). By the same procedure used to prepare 1, 6a was converted to 3 as a white solid (14 mg, 74\%): mp $210{ }^{\circ} \mathrm{C}$ dec.; ${ }^{1} \mathrm{H}-\mathrm{NMR}$ (400 MHz, $\left.\mathrm{D}_{2} \mathrm{O}\right) \delta$ 1.69-1.79 (m, 2H), 1.88-1.94 (m, 2H), 4.02 $(\mathrm{dd}, 1 \mathrm{H}, J=12.8 \mathrm{~Hz}, 5.2 \mathrm{~Hz}), 4.43(\mathrm{t}, 1 \mathrm{H}, J=5.6 \mathrm{~Hz}), 4.70$ (d, $1 \mathrm{H}, J=5.6 \mathrm{~Hz}), 5.93(\mathrm{~d}, 1 \mathrm{H}, J=5.6 \mathrm{~Hz}), 8.13(\mathrm{~s}, 1 \mathrm{H}), 8.18(\mathrm{~s}$, $1 \mathrm{H}) ;{ }^{13} \mathrm{C}-\mathrm{NMR}\left(100 \mathrm{MHz}, \mathrm{D}_{2} \mathrm{O}\right) \delta 23.48(\mathrm{~m}), 28.50(\mathrm{~m}), 67.20$, 75.47, 86.46 (m), 88.01, 122.64, 131.65, 142.02, 154.98, 157.60; HRMS (ESI) calcd for $\mathrm{C}_{11} \mathrm{H}_{15} \mathrm{~N}_{8} \mathrm{O}_{5} \mathrm{P}, 371.0903$, found 371.0970 .

Ammonium 2-((2R,3R,4S,5R)-5-(6-amino-9H-purin-9-yl)3-azido-4-hydroxy-tetrahydrofuran-2-yl)ethylphosphonate (4). By the same procedure used to prepare $\mathbf{1 ,} \mathbf{6 b}$ was converted to 4 as a white solid (26 mg, 81\%): mp $194{ }^{\circ} \mathrm{C} \mathrm{dec}$.; ${ }^{1} \mathrm{H}-\mathrm{NMR}$ $\left(400 \mathrm{MHz}, \mathrm{D}_{2} \mathrm{O}\right) \delta 1.65-1.93(\mathrm{~m}, 4 \mathrm{H}), 4.04(\mathrm{dd}, 1 \mathrm{H}, J=12.8$ $\mathrm{Hz}, 5.6 \mathrm{~Hz}), 4.14(\mathrm{t}, 1 \mathrm{H}, J=5.6 \mathrm{~Hz}), 4.59(\mathrm{~s}, 1 \mathrm{H}), 4.92(\mathrm{t}, 1 \mathrm{H}$, $J=5.6 \mathrm{~Hz}), 5.87(\mathrm{~d}, 1 \mathrm{H}, J=5.6 \mathrm{~Hz}), 8.10(\mathrm{~s}, 1 \mathrm{H}), 8.16(\mathrm{~s}, 1 \mathrm{H})$; ${ }^{13} \mathrm{C}-\mathrm{NMR}\left(100 \mathrm{MHz}, \mathrm{D}_{2} \mathrm{O}\right) \delta 24.06(\mathrm{~m}), 29.81(\mathrm{~m}), 66.80$, 76.71, 84.98 (m), 90.26, 121.47, 142.78, 151.39, 154.84, 157.69; HRMS (ESI) calcd for $\mathrm{C}_{11} \mathrm{H}_{15} \mathrm{~N}_{8} \mathrm{O}_{5} \mathrm{P}, 371.0903$, found 371.0974 .

Ammonium 2-((2R,3R,4S,5R)-4-amino-5-(6-amino-9H-purin-9-yl)-3-hydroxy-tetrahydrofuran-2-yl)ethylphosphonate (5). By the same procedure used to prepare 1, 7a was converted to $\mathbf{5}$ as a white solid (16 mg, 70\%): mp $140{ }^{\circ} \mathrm{C} \mathrm{dec}$.; ${ }^{1} \mathrm{H}-\mathrm{NMR}$ (600 MHz, $\left.\mathrm{D}_{2} \mathrm{O}\right) \delta$ 1.67-1.74 (m, 2H), 1.88-1.93 (m, 2H), 4.06 $(\mathrm{m}, 1 \mathrm{H}), 4.21(\mathrm{dd}, 1 \mathrm{H}, J=5.4 \mathrm{~Hz}, 1.8 \mathrm{~Hz}), 4.82(\mathrm{dd}, 1 \mathrm{H}, J=$ $8.4 \mathrm{~Hz}, 5.4 \mathrm{~Hz}$ ), 5.89 (d, 1H, $J=7.2 \mathrm{~Hz}), 8.03$ (s, 1H), 8.17 (s, $1 \mathrm{H}) ;{ }^{13} \mathrm{C}-\mathrm{NMR}\left(150 \mathrm{MHz}, \mathrm{D}_{2} \mathrm{O}\right) \delta 22.36,27.64(\mathrm{~m}), 56.16$, 72.90, 86.49, 86.99 (m), 140.90, 149.85, 153.44, 156.24, 175.12; HRMS (ESI) calcd for $\mathrm{C}_{11} \mathrm{H}_{17} \mathrm{~N}_{6} \mathrm{O}_{5} \mathrm{P}, 345.1076$, found 345.1085 .

Ammonium 2-((2R,3R,4S,5R)-3-amino-5-(6-amino-9H-purin-9-yl)-4-hydroxy-tetrahydrofuran-2-yl)ethylphosphonate (6). By the same procedure used to prepare $1,7 \mathrm{~b}$ was converted to 6 as a white solid (10 mg, 71\%): mp $90-92{ }^{\circ} \mathrm{C} \mathrm{dec} .{ }^{1} \mathrm{H}-\mathrm{NMR}$ $\left(400 \mathrm{MHz}, \mathrm{D}_{2} \mathrm{O}\right) \delta 1.38(\mathrm{~m}, 1 \mathrm{H}), 1.55(\mathrm{~m}, 1 \mathrm{H}), 1.82(\mathrm{~m}, 1 \mathrm{H})$, $1.98(\mathrm{~m}, 1 \mathrm{H}), 3.21(\mathrm{t}, 1 \mathrm{H}, J=6.6 \mathrm{~Hz}), 3.83(\mathrm{~d}, 1 \mathrm{H}, J=4.8 \mathrm{~Hz})$, $5.84(\mathrm{~d}, 1 \mathrm{H}, J=4 \mathrm{~Hz}), 7.96(\mathrm{~s}, 1 \mathrm{H}), 8.09(\mathrm{~s}, 1 \mathrm{H}) ;{ }^{13} \mathrm{C}-\mathrm{NMR}$ $\left(150 \mathrm{MHz}, \mathrm{D}_{2} \mathrm{O}\right) \delta 26.09(\mathrm{~m}), 28.86,56.05,75.75,86.48(\mathrm{~m})$, 89.16 (m), 119.27, 140.17, 148.91, 153.23, 155.97; HRMS (ESI) calcd for $\mathrm{C}_{11} \mathrm{H}_{17} \mathrm{~N}_{6} \mathrm{O}_{5} \mathrm{P}, 345.1076$, found 345.1092.

Acknowledgments. This work was supported by the grant from Duk-myung, Huh Jin-Kyu Memorial Fund of Chonbuk National University.

\section{References}

1. Choo, Q. L.; Kuo, G.; Weiner, A. J.; Overby, L. R.; Bradley, D. W.; Houghton, M. Science 1989, 244, 359-362.

2. Sarbah, S. A.; Younossi, Z. M. J. Clin. Gastroenterol. 2000, 30, 125-143.

3. Hepatitis, C. Week. Epidemiol. Rec. (World Health Organization) 1996, 71, 346-349.

4. Manns, M. P.; McHutchison, J. G.; Gordon, S. C.; Rustgi, V. K.; Shiffman, M.; Reindollar, R.; Goodman, Z. D.; Koury, K.; Ling, M.; Albrecht, J. K. Lancet 2001, 358, 958-966.

5. Pierra, C.; Amador, A.; Benzaria, S.; Cretton-Scott, E.; D'Amours, M.; Mao, J.; Mathieu, S.; Moussa, A.; Bridges, E. G.; Standring, D. N.; Sommadossi, J.-P.; Storer, R.; Gosselin, G. J. Med. Chem. 2006, 49, 6614-6620. 
6. Roberts, S.; Cooksley, G.; Shaw, D.; Berns, H. K.; Brandl, M. T.; Fettner, S. H.; Hill, G.; Ipe, D.; Klumpp, K.; Mannino, M.; O’Mara, E.; Tu, Y.; Washington, C. B. Presented at the 41st EASL, Vienna, Austria; Abstract 731.

7. Holy, A. Curr. Pharm. Des. 2003, 9, 2567-2592.

8. Koh, Y. H.; Shim, J. H.; Wu, J. Z.; Zhong, W.; Hong, Z.; Girardet, J. L. J. Med. Chem. 2005, 48, 2867-2875.

9. Kim, B. T.; Kim, S. K.; Lee, S. J.; Hwang, K. J. Bull. Korean Chem. Soc. 2004, 25, 243-248.

10. Robins, M. J.; Sarker, S.; Sumano, V.; Wnuk, S. F. Tetrahedron 1997, 53, 447-456.

11. Pfitzner, K. E.; Moffatt, J. G. J. Amer. Chem. Soc. 1963, 85, 30273028 .
12. Jones, G. H.; Hamamma, E. K.; Moffatt, J. G. Tetrahedron Lett. 1968, 55, 5731-5734.

13. Mashimo, K; Sato, Y. Tetrahedron 1970, 26, 803-812.

14. Herzig, J.; Nudelman, A.; Gottlieb, H. E.; Fischer, B. J. Org. Chem. 1986, $51,727-730$.

15. Freeman, G. A.; Rideout, J. L.; Miller, W. H.; Reardon, J. E. J. Med. Chem. 1992, 35, 3192-3196.

16. Jones, G. H.; Moffatt, J. G. J. Amer. Chem. Soc. 1968, 26, 53375338.

17. Kim, B. S.; Kim, B. T.; Hwang, K. J. Bull. Korean Chem. Soc. 2009, 30, 1391-1393.

18. Hamersma, J. W.; Snyder, E. I. J. Amer. Chem. Soc. 1965, 87, 39853986. 